\title{
Securitization of Islam: A Case of Muslims in Cyprus
}

\author{
Riskiansyah Ramadhan \\ Universitas Indonesia \\ riskiansyah.ramadhan@ui.ac.id
}

\begin{abstract}
This paper analyzes how Muslims, as a religious community in the Republic of Cyprus, became an object of discrimination. Furthermore, the paper tries to understand and describe how Muslims' daily lives are as a minority in the country through a case study approach. The study found that Islamophobic incidents often occur in the form of hate speech and discrimination in the workplace, schools, and even government institutions. These Islamophobic behaviors are an attempt to securitize Islam on the island. Moreover, prominent figures like political and religious leaders actively contribute to the phenomena of this securitization. Although religious freedom is protected by law, the Christian Greek Cypriot is not ready to accept multiculturalism. Thus, both government and society, and the community must support each other in bringing about peace in the country.
\end{abstract}

Keywords: Cyprus, Discrimination, Islamophobia, Securitization

\section{Introduction}

The Middle East region is known as a region with a majority population that adheres to Islam. However, this is not the case with the Republic of Cyprus (RoC), ${ }^{1}$ a country in the Eastern Mediterranean, which is a country in the Middle East with a Muslim population as a minority. While other Muslims in the region

${ }^{1}$ Cyprus was a part of the Ottoman Empire from 1571 until 1878, where the two communities, the Greek and Turkish Cypriots lived together in relative harmony during that period. In 1878, the Ottoman Empire handed the administration of the island to the United Kingdom. Then, in 1960, Cyprus became independent with London-Zurich accords that created the Republic of Cyprus. The division into two different administrations happened in 1974 when the Greek junta regime staged a coup and claimed the annexation. In response, Turkey staged an intervention. Since then, the island has been divided into two different administrations, the internationally recognized Greek Cypriot administration and the Turkish Republic of Northern Cyprus, which is not recognized by any country in the world except Turkey. See further Meltem Muftuler-Bac and Aylin Guney, "The European Union and the Cyprus Problem 19612003", Middle Eastern Studies, Volume 41, Number 2, (March 2005), p. 281-293

AJIS : Academic Journal of Islamic Studies, vol. 5, no. 2, 2020

IAIN Curup - Indonesia | ISSN 2580-3174, (p); 2580-3190 (e)

DOI: $10.29240 /$ ajis.v5i2.1947 | page: $179-196$ 
enjoy freedom in practicing religious practices, in terms of worship, education, and expressions that show religious symbols in dress, Muslims in the RoC might not feel such things.

The phenomenon then raises the question of how to live as a minority in a country where the majority of the population embraces Christianity? Does the government of the RoC guarantee religious freedom and evenly accommodate the spiritual needs there? So, how about the facts that occur in social life in the RoC? These questions are indeed closely related to the crucial issue of guaranteeing religious freedom, especially concerning rights equality among religions and other sects in the country.

Several studies focus on the development of Islam in both Northern Cyprus or the RoC. Altay Nevzat \& Mete Hatay (2009) researched how Islam was declined in Cyprus during the Ottoman era to the twenty-first century. They found that besides the British government, the ottoman policy in Cyprus has also contributed to the rise of secularization. Some other scholars, like Ateşin (2006), focus on the phenomena of secularism in Northern Cyprus. Ateşin (2006) argued that the first step of Cyprus's secularization began in the 1892s when every Muslim teacher was absorbed into the public service.

İçim Özenli Özmatyatli \& Ali Efdal Özkul (2013), however, have argued that the British government intervention in the religious institutions and educational process that has contributed significantly to the secularization of Cyprus begun in 1878, the time that British administrated Cyprus for the first time. Furthermore, Ramadhan (2020) has conducted a study on the roots of secularism in Northern Cyprus and how ambitious Turkey is to implement its Islamization policy. The author found that the mentioned scholars above have only discussed the phenomena of Islam in Northern Cyprus without mentioning any phenomena of securitization on Islam in the RoC. This article, furthermore, might give a contribution and complete the gap of the literature on Muslim society.

Discrimination in the RoC is closely related to the history of politics in the country. In addition, the problem of identity also contributes to the phenomenon of discrimination and Islamophobia on the island. During their period, the Ottoman applied Millet System to organize the empire's population, including in Cyprus. This system was a form of indirect rule based on the religious difference with three basic millets: the Greek, the Jewish, and the Armenian communities. This system was successfully applied and highly functioning, which enabled the Ottoman to categorize its religious groups into 
autonomous and self-regulating communities. ${ }^{2}$ Accordingly, the island's two communities were institutionalized as a distinct community, both political and religious, and were able to choose their own judicial and administrative officials. The separation of the two regions, indeed, cannot be separated from the influence of the system that was once applied to the people of Cyprus.

Considering that governance in Cyprus is divided into two administrative regions, this article will focus on the internationally recognized administrative areas in the RoC. The Turkish Cypriot, the well-known Turkish Republic of Northern Cyprus (TRNC) or Northern Cyprus, is not recognized by any country in the world except Turkey. In addition, The RoC in the south is a region with the majority of its population being Christians, while Islam is a minority religion there. While the TRNC is a country with approximately 94 percent of the population is Muslim. This is the reason why the study will only focus on the phenomenon of Islam in the RoC. However, the discussion in this article will also review some of the aspects of the TRNC region.

This research is an analytical descriptive study in which the author describes Islam's securitization in the form of hate speech and discrimination in the RoC. Data analysis is done through three techniques. First is data collection that correlates with the research topic, and then selecting and reducing those data. The selected data are then presented systematically in words. The final step is to conclude by interpreting the data collected, reduced, and presented in descriptions and explanations.

\section{Muslims in the Republic of Cyprus as a minority}

Many said that the presence of Muslims in Cyprus could be traced to the seventh century, ${ }^{3}$ but Islam took root, grew, and institutionalized on the island in 1571 under the Ottoman Empire administration when they conquer the island. Following the conquest of Cyprus, the Sultan ordered settlement of the island by migrants consisting of 1,689 families from twelve different regions of Anatolia as well as 4000 soldiers who participated in the war and remained on Cyprus. ${ }^{4}$ Others also insisted that the substantial portion of the island's Muslims were Christian converts. Those who converted to Islam were from Latin

2 Karen Barkey and George Gavrilis, "The Ottoman Millet System: NonTerritorial Autonomy and Its Contemporary Legacy," Ethnopolitics, Volume 15, Number 1 (December 2015), p. 24-26

${ }^{3}$ Ali Dayioglu and Mete Hatay, "Cyprus" in Jorgen S. Nielsen (ed) Yearbook of Muslims in Europe, Volume 2, Leiden: Koninklijke Brill (2010), p. 125

${ }^{4}$ Birol Yesilada, "Islam and the Turkish Cypriots," Social Compass, Volume 56, Number 1 (2009), p. 50 
Catholic, Armenian, or Orthodox Christian, whose motivations are various. Some of those who converted hoped to avoid taxes imposed by the Ottoman rulers, while others were due to intermarriages or fear-inspired conversion..$^{5}$ Both opinions are probably correct, as several documents were found stating that some Christian residents converted to Islam in the early Ottoman Empire. ${ }^{6}$

Other than Muslims, Jews also represent a small number of population. With a history mirroring their experiences elsewhere on the European continent, Jews, therefore, represent the longest lasting minority in Cyprus who sent there in $722 \mathrm{BC}$ after the Assyrian conquest of Judea. At some times during the fourteenth century, appears that Roma first arrived on the island. They represent a tiny minority and remain characterized by poverty and discrimination. They also live with lower living standards and educational achievements. Turks were the third diasporic population to find themselves on the island and were the most significant minority there. However, since the provision of north and south in 1974, new minorities emerged on both sides of the island with ethnic cleansing attempts. Apart from three dispersed minorities of Jews, Romanies, and Turks, Cyprus also counts three other tiny communities recognized by the 1960 constitution, including Latin, Maronites, and Armenians. ${ }^{7}$

According to the Worldmeters, the current population of the RoC (as of June 2020) is $1,206,919$, which is equivalent to 0.02 percent of the total world population. ${ }^{8}$ Demographically, Christian Orthodox made up to 95 percent out of the total population. In comparison, other religious communities are minorities consist of Armenian or Maronite 0.9 percent, Roman Catholic 1.0 percent, the Church of England 1.0 percent, Muslim 0.6 percent, and with 1.3 percent not stating or choosing another denomination. ${ }^{9}$ These percentages put Muslims as

${ }^{5}$ Areti Demosthenous, "Cyprus: National Identity and Images of Self and Others in History of Textbooks," in Elie Podeh and Samira Alayan (ed) Multiple Alterities: Views of Others in Textbooks of the Middle East, Jerusalem: Palgrave Macmillan (2018), p. 256

${ }^{6}$ Altay Nevzat and Mete Hatay, "Politics, Society and the Decline of Islam in Cyprus: From the Ottoman Era to the Twenty-First Century," Middle Eastern Studies, Volume 45, Number 6 (November 2009), 912

7 Panikos Panayi, "Introduction: Ethnic Minority Creation in Modern Europe: Cyprus in Context," in Andrekos Varvana, Nicholas Coureas, and Marina Elia (ed) The Minorities of Cyprus: Development Patterns and the Identity of the Internal-Exclusion, Newcastle: Cambridge Scholars Publishing (2009), p. 16-19

8 See Worldometer, "Population of Cyprus." Accessed on June 18, 2020. https://www.worldometers.info/world-population/cyprus-population/

${ }^{9}$ Since 1974, the number of the Christian population in the south part of RoC increased from year to year. On the contrary, the Muslim community on the island is 
minority religious group, making them the tiniest and smallest in the south part of the RoC. Moreover, the Muslim population in RoC, north and south, occupies the last position (not including Israel) of 22 countries in the Middle East and North Africa region, with approximately 18 percent of the population.

\section{The reality of religious freedom}

A further question, then, does the government of the RoC has a commitment to bringing about multiculturalism in the country and protect everyone's rights? Article 18 of the 1960 Constitution of the RoC with amendments through 2013 guarantees freedom of thought, conscience, and religion. Moreover, the constitution also provides in principle that the administration of the RoC will not discriminate against any religion or religious institution. Furthermore, It also states that all religions are equal before the law, and every person is free to manifest his belief in worship, teaching, practice, either individually or collectively, in private or in public. Also, everyone is free to change his religion or belief. 10

The situation of freedom of religion in the RoC is very complicated. While Greek Orthodox Christians constitute the largest religious community in the south, their members in the north represent a small minority with only a few hundred people. The RoC has tried its best to protect the freedom of the citizens on the island by considering the diversity of religious groups on the island. The paragraphs of article 18 in the constitution show the RoC's commitment to religious freedom. Moreover, Article 110 of the constitution also provides the autocephalous Greek Orthodox Church of Cyprus along with the Vakf,11 an Islamic institution, exclusive rights of regulating and administering its internal

shrinking over the year. For further information on complete data, see the worldmeter, "Population of Cyprus." Accessed on June 18, 2020. https://worldpopulationreview.com/countries/cyprus-population/. See also the statistical service provided by the government of the Republic of Cyprus. See even further data from the government. Accessed on June 18, 2020. https://www.mof.gov.cy/mof/cystat/statistics.nsf/populationcondition_22main_en/p opulationcondition_22main_en?OpenForm\&sub=1\&sel=2

${ }^{10}$ See Constitute, Cyprus' Constitution of 1960 with Amendments through 2013. $\begin{array}{llll}\text { Accessed on June } & 12, & \end{array}$ https://www.constituteproject.org/constitution/Cyprus_2013.pdf?lang=en

${ }^{11}$ Vakf is religious institutions in Cyprus launched on September 15, 15700, by converting the cathedral of the city into a mosque and laying it as the first religious foundation there. See further Netice Yildiz, "The Vakf Institution in Ottoman Cyprus" in Michalis N Michael, Matthias Kappler, and Eftihios Gavriel (ed) Ottoman Cyprus: A Collection of Studies on History and Culture, Wiesbaden: Otto Harrassowitz GmbH \& Co. KG (2009), p. 117 
affairs and properties. ${ }^{12}$ A privilege for Muslims that other religious groups could not afford.

The privilege of both institutions is due to the bi-communal nature of Cyprus. This privilege then made in the constitution for the Greek Orthodox Church of Cyprus and the institution of waqf and the law of principal waqf. Article 23 of the constitution also secures property belonging to mosques and other Muslim religious institutions, exempt from taxes, and is eligible for government subsidies. However, after 1974, the Waqf institution lost its control in the south and operated only in the north. Despite this, the Greek Cypriot government established the Turkish Cypriot Properties Management to maintain all other Turkish Cypriot properties in the south. ${ }^{13}$ Once more, this fact constitutionally shows the commitment of the RoC to the freedom of religion.

These institutions, alongside three other religious groups recognized by the constitution, Maronite Catholics, Armenian Orthodox, and Roman Catholics, are exempt from tax. All groups also receive significant subsidies and financial assistance from the state, which generally allocated for construction work, repairs, monasteries, mosques, cemeteries, etc. Other religious groups in the country can also register as non-profit organizations and are granted taxexempt status but are unfortunately not eligible for the allocation of any financial support from the government

\section{Securitization of Islam}

The RoC government's efforts to guarantee religious freedom are contained in the nation's constitution. However, the facts that occur do not represent the application and practice of the constitution. There have been many incidents of discrimination against religious diversity in the RoC, particularly to Muslims. This is a form and effort of securitization of Islam, which is seen as a threat. Securitization refers to exceptional moves, measures, and procedures taken beyond the established rule. The existence of Muslims in the RoC is believed to be a spectrum that should be securitized because it is presented as

${ }^{12}$ See Constitute, Cyprus' Constitution of 1960 with Amendments through 2013. Accessed on June 12 , 2020. https://www.constituteproject.org/constitution/Cyprus_2013.pdf?lang=en

13 Ali Dayioglu and Mete Hatay, Ali Dayioglu and Mete Hatay, "Cyprus" in Jorgen S. Nielsen (ed) Yearbook of Muslims in Europe, Volume 5, Leiden: Koninklijke Brill (2013), p. 176 
an existential threat, requiring emergency measures, and justifying outlawed procedures. ${ }^{14}$

The actors who "speak security" play an essential role in achieving a successful securitization. These actors are key in constructing and identifying these threats and then declare them as an existential threat that requires extraordinary measures and outlawed procedures. ${ }^{15}$ Since the 1990s, the RoC became the country that receives migrants from the Third World and Eastern Europe. The influx of migration, which most Muslims, is increasing over the year. To tackle this phenomenon, the RoC has begun expelling foreign nationalism citing concerns over security threats and changing demographics due to a migration crisis. In order to adopt a broader conception of securitization, the author would not only focus on speech acts but also institutions and policymaking attitude towards the discriminatory phenomena against Muslims.

\section{Islamophobic incidents}

Islamophobia is a form of hatred for everything related to Islam. The emergence of Islamophobia in Cyprus is caused by feelings of superiority and concerns about the flow of migration that Muslims dominate. They see themselves better than others, specifically migrants who are mostly Muslims, whom they see as stupid who do not know Greek Cypriot culture and identity. Moreover, they also depict those migrants as barbarians who do not have any culture. They also strongly affirmed a sense of Greek Cypriot national pride and perceived migrants as a threat to the reproduction of their national identity. ${ }^{16}$

A feeling of superiority and excessive fanaticism of the Greek Cypriot then manifested into violence and attack. A feeling of superiority and excessive fanaticism of the Greek Cypriot then manifested into violence and attack. In April 2012, several young Greek Cypriot set fire on a historical mosque in Limassol that had been renovated at the Turkish Cypriot Muslim community's request. ${ }^{17}$ We should also not forget the arson attack on a historic mosque located in the

14 Barry Buzan, Ole Waever and Jaap de Wilde, Security: A New Framework for Analysis, London: Lynne Publisher (1997), p. 23-24

15 Jocelyne Cesari, "Securitization of Islam in Europe," Die Welt des Islams, Volume 52, Number 3/4 (2012), 433

16 Ian Law, Mediterranean Racism: Connections and Complexities in the Racialization of the Mediterranean Region, New York: Palgrave Macmillan (2014), p. 8586

17 Marianna Tsatsou, "Fire in Cypriot Mosque Fuels Political Issue." Greek Reporter. Accessed on June 19, 2020. https://eu.greekreporter.com/2012/04/17/firein-cypriot-mosque-fuels-political-issue/ 
Denya area inside the territories of the Greek Cypriot administration on February 22, 2016.18 The most recent attack on the Köprülü Mosque in the Cypriot city of Limassol happened in early June this year. The mosque was petrol bombed and had graffiti written on its outer walls saying "immigrants, Islam not welcomed." 19 These kinds of attacks show that despite the government's effort to guarantee equal rights to every citizen, some people are not ready to accept multiculturalism as a social fact that must be lived.

Following the departures of the Turkish Cypriot from the south, there were 102 mosques as well as four tekkes and 148 cemeteries. A report prepared the Turkish Cypriot leadership in 2006, published that 16 of these mosques have been destroyed. Of the cemeteries, 43 have also been destroyed. Notwithstanding, the RoC has spent its budget for reconstruction and reparation, and the amount had significantly increased in 2004. ${ }^{20}$ Some mosques also have been declared by the RoC as ancient monuments. These mosques have undertaken expenses for restoration and maintenance, in which four are funded by the state and used by Muslims for religious purposes. ${ }^{21}$ However, the government's efforts in carrying out the constitutional mandate were not supported by the people of the RoC. Incidents of attack and arson of mosques, as well as vandalism, are some examples of these negative phenomena.

Islamophobia also threatens school students in the RoC. In September 2019, the headmaster of a public secondary school sent away a Muslim student for wearing a headscarf. Unless she removes it, she will not return. ${ }^{22}$ This incident violated the constitution of the $\mathrm{RoC}$, which protects the freedom to worship, teach, and practice religion. In addition to being manifested in the form of action, islamophobic attitudes can also occur in the form of hate speech. The

18 Anadolu Agency, "Arson attack staged on mosque in Greek Cyprus, leaders condemn assault," Hurriyet Daily News. Accessed on June 19, 2020. https://www.hurriyetdailynews.com/arson-attack-staged-on-mosque-in-greekcyprus-leaders-condemn-assault-95551

19 Paul Antonopoulos, "Mosque in Limassol attacked," Greek City Times. Accessed on June 19, 2020. https://greekcitytimes.com/2020/06/04/mosque-inlimassol-attacked/

${ }^{20}$ Ali Dayioglu and Mete Hatay, "Cyprus" in Jorgen S. Nielsen (ed) Yearbook of Muslims in Europe, Volume 6, Leiden: Koninklijke Brill (2014), p. 160

21 Achilles Emilianides et al., "Allocation of Religious Space in Cyprus," The Cyprus Review, Volume 23, Number 1 (Spring 2011), p. 105

22 See further "Religious freedom report refers to headscarf incident in high school," Cyprus Mail. Accessed on June 15, 2020. https://cyprusmail.com/2020/06/10/religious-freedom-report-refers-to-headscarf-incident-in-highschool/ 
Council of Europe, in 1997, adopted a recommendation on hate speech which defined as:

"covering all forms of expression which spread, incite, promote or justify racial hatred, xenophobia, anti-Semitism or other forms of hatred based on intolerance, including intolerance expressed by aggressive nationalism and ethnocentrism, discrimination and hostility against the minority, migrants and people of immigrant origin."

Not only a lexical-semantic level and visual aspect, but also hate speech could be manifested into body language and paraverbal communication. ${ }^{23}$ In the RoC, Church and its leaders played an essential role as they also represent the most conservative ideology and views towards some issues. These religious leaders often say hate speech toward Muslims. At the end of 2017, the Archbishop of Cyprus once spread intolerance expression describing Muslims as a threat to the nation. He urged people to fight against Muslims that, according to him, intended to alter Cypriot people's national and cultural identity. ${ }^{24}$ The archbishop also often expresses his agreement with ELAM's, far-right party, statement towards Muslims. Again, it is inseparable from the political dimension that perceived Turks as an enemy. Moreover, locals failed to differentiate national origins between Arab and non-Arab. Furthermore, all Muslims than in their eyes are Turks and, therefore, their enemy.

\section{Lack of access to education}

In the field of education, the school enrolment criteria discriminatory application happened to the Turkish Cypriot parents. Greek Cypriot parents seem to have no trouble enrolling their children in schools that are not the closest to where they live and which have higher proportions of Greek Cypriot pupils. ${ }^{25}$ More surprisingly, there are no state-supported Islamic schools in the south, while instruction in the Greek Orthodox religion is compulsory in primary and secondary schools. Turkish Cypriot pupils who attend schools in the south may receive religious education if there are reasonable numbers of them. We

${ }^{23}$ See further Gabriella B. Klein, "Applied Linguistics to Identify and Contrast Racist' Hate Speech': Cases from the English and Italian Language," Applied Linguistics Research Journal, Volume 2, Number 3 (2018), p. 1-16. See also Alexander Brown, What Is hate Speech? The Myth of Hate", Law and Philosophy, Volume 36 (2017), p. 419-468

${ }^{24}$ See further KISA Condemns the Latest bout of Hate Speech by the Archbishop of Cyprus. Accessed on June 15, 2020. https://kisa.org.cy/kisa-condemns-the-latestbout-of-hate-speech-by-the-archbishop-of-cyprus/

${ }^{25}$ See ECRI Report n Cyprus (fourth monitoring cycle). Adopted on March 23, 2011. Accessed on June 26, 2020. https://rm.coe.int/09000016808b5638 
will also find no Turkish primary school opened for Turkish Cypriot despite the provisions of the constitution of the RoC and repeated assurances by the RoC administration to the United Nations (UN) Secretary-General. ${ }^{26}$ Relating to education, the government has not shown its seriousness in providing equal access to the communities in the country. On the one hand, this shows that the UN lacks commitment to Turkish Cypriot's fate, particularly the Muslim community on the island. On the other hand, this would be an Islamophobic attitude carried out by the government or the RoC, and it might also be an attempt to securitize Islam in the southern part of the island.

To a broader extent of discrimination, there is also segregation among students evidenced by a visible "grouping" of students based on their ethnicity, Cypriot and non-Cypriot. This phenomenon is because of the rise of ethnic nationalism, which had its roots in enosis, aspiration to unify with Greek..$^{27}$ This idea of enosis is produced/reproduced in schools, in which education and curricula play a crucial role in indoctrination. The Greek Cypriot educational authorities have continued to make Hellenocenism prevail in the domain of education and curricula. Furthermore, education has also remained a pivotal mechanism to educate the younger generation into the Greek Cypriot historical narrative, including the desire for reunification of the island with Greece. ${ }^{28}$

\section{Institutional discrimination}

Meanwhile, the Council of Ministers seems directly continued to practice institutional discrimination in relation to the acquisition of RoC nationality. The constitution of the RoC introduces three modes of citizenship acquisition: acquisition by descent, acquisition via registration, and acquisition via naturalization. Turkish children, however, face difficulty in obtaining citizenship status of the RoC. According to the law of citizenship of the RoC, Article 198 (1) provided that:

"a person born in Cyprus on or after the 16th day of August 1960 shall be a citizen of the Republic if at the time of this person's birth any one of his parents was a citizen of the Republic or, in the case at the time of birth

${ }^{26}$ Ali Dayioglu and Mete Hatay, "Cyprus" in Jorgen S. Nielsen (ed) Yearbook of Muslims in Europe, Volume 6, Leiden: Koninklijke Brill (2014), p. 165

27 Robert Holland, British and the revolt in Cyprus 1954-1959, Oxford: Carlendon Press (1998), p. 8

${ }^{28}$ Stavroula Philippou, "What Makes Cyprus European? Curricular Responses of Greek-Cypriot Civic Education to 'Europe'", Journal of Curriculum Studies, Volume 41, Number 2 (March 2009), p. 206 
his parents were not alive, any one of them would, but for his or her death, have been entitled to become a citizen of the Republic."

According to the law above, any Turkish Cypriot children born after that day could be a citizen of the RoC if one of their parents was a citizen of the republic. However, this provision is not applicable for a permanent resident abroad unless the child's birth is registered in the prescribed manner. Furthermore, there are two exceptions to this general rule, one of which is directed against Turkish national settling in the north. The exemptions provided that children born to parents, one of whom unlawfully entered or resided in the republic, do not automatically become the citizens of the republic even if their other parent holds or would have been entitled to Cypriot citizenship. ${ }^{29}$ This is an attempt to prevent Turkish Cypriot, who are mostly Muslims from acquiring citizenship of the republic. And again, it is obviously a way taken by the RoC to securitize Islam because of fear about demographic changes on the island.

Not only to Turkish but also Greek Cypriot shows dislike to other people they see different from them, moreover if their religious affiliation is Islam. It happened to a man, E.T., born in the RoC from naturalized Palestinian origin father. When this man married a Lebanese citizen and had a son of his own, however, he was informed that the Civil Registry and Migration Department could not register the child as a Greek Cypriot because the religious affiliation of the father was Muslim. Therefore, the child should be registered as a Turkish Cypriot. Moreover, the Department also suggested to the man that his original ancestors' assignment into the Greek Cypriot community three generations back had been flown and should be re-assigned into the Turkish Cypriot community. ${ }^{30}$ This case mainly shows that the Civil Registry and Migration Department officials had discriminatively treated people because of their religious affiliation. This also indicates that the implementation of the law still being violated, event at the institutional level.

\section{Parties-supported Islamophobia}

The unfair policy is inseparable from the political problems in the country. The Turkish Cypriot's negative stigma has long been occurring after the

29 Nikos Trimikliniotis, "Nationality and Citizenship in Cyprus since 1945: Communal citizenship, gendered nationality and the adventures of a post-colonial subject in a divided country", in Rainer Baubock, Benhard Perching and Wiebke Sievers (ed) Citizenship Policies in the New Europe: Expanded and Updated Edition, Amsterdam: Amsterdam University Press (2009), p. 397-399

30 Olga Demetriou, Migration into the Cyprus Conflict and the Cypriot Citizenship Regime, Oslo: Peace Research Institute Oslo (2019), p. 23 
Greek and Turkish nationalism politicized the island. During the conquest of the Ottoman Empire over the island, with some provisions, religious freedom was guaranteed, and the people could live peacefully. Even during the administration of the British on the island, the two communities lived in relative harmony. ${ }^{31}$ However, the idea of unification with Greece has long become the goal that the Greek Cypriot want to achieve. This idea of enosis is still indoctrinated to the young generation of the Greek Cypriot until today, as discussed earlier.

Political problems also trigger discrimination against the population of Turkish Cypriot. An event of the self-declaration of the independence of TRNC on November 15, 1983, might be one of those triggers. The declaration was outlawed and incompatible with the 1960 Treaties of Establishment and Guaranteed binding on Cyprus, Turkey, Greece, and the United Kingdom. The UN Security Council, hence, passed Resolution 541 that not only called the declaration of independence legally invalid, it also called on all states not to recognize any Cypriot state other than the RoC.32 This resolution was followed six months later in May 1984 by another resolution. Prompted by the Turkish Cypriots' failure to rescind their declaration of independence and by the decision of Turkey and TRNC to exchange ambassadors, the Security Council then passed Resolution 550. This not only reiterated calls for states not to recognize the TRNC but also went further and called on them not to facilitate or assist the aforesaid secessionist entity. ${ }^{33}$

The negative attitude of the Greek Cypriot also can be seen through the rejection of the Annan Plan proposed by the UN to both Greek and Turkish Cypriot to reunify the two sides. The majority, 65 percent, of the Turkish Cypriot voted to accept the Annan Plan. Meanwhile, a substantial majority of Greek Cypriot, 76 percent, reject the plan. ${ }^{34}$ There were many reasons behind this rejection, ranging from economic, social, and security factors. However, the biggest concern to the Greek Cypriot was the issue of citizenship definition. ${ }^{35}$

${ }^{31}$ Panikos Panayi, Introduction: Ethnic Minority Creation in Modern Europe ..., 18

32 See Resolution 541 of November 18, 1983, United Nations Security Council Resolution. Accessed on June 15, 2020. http://unscr.com/en/resolutions/541

${ }^{33}$ See Resolution 550 of November 18, 1984, United Nations Security Council Resolution. Accessed on June 15, 2020. http://unscr.com/en/resolutions/550

${ }^{34}$ Graig Webster, "Division or Unification in Cyprus? The Role of Demographics, Attitudes and Party Inclination on Greek Cypriot Preferences for a Solution to the Cyprus Problem", Ethnopolitics, Volume 4, Number 3 (September 2009), p. 300

35 Van Coufoudakis, "Cyprus-The Referendum and Its Aftermath," Cyprus Review, Volume 6, Number 2 (2004), p. 73-75 
Many leaders of political parties on the island also reject the plan as it would give many disadvantages to the entity of the RoC.

The emergence of political parties, particularly far-right, is always related to the situation and conditions in Cyprus at the time. These parties have been linked with nationalistic, anti-Turkish (Muslim), anti-communist, and to a lesser extent, anti-British feelings. In Southern Cyprus, the far-right Ethniko Laiko Metopo (ELAM), which is a sister party to Greece's Golden Dawn, has significantly contributed to the spreading of Islamophobia in the southern part of Cyprus. ${ }^{36}$ ELAM was not the only far right-wing party in the RoC. There appeared several radical right-wing parties on the island before 1974, including the National Radicalise Union of Cyprus (EREK) in 1931, Greek extreme-right organization X in the 1940s, and National Organisation of Cypriot Fighters (EOKA) in 1955-1959. After 1974, there emerged incredibly right and the unionist line, such as the DISY party, and many other movements. These parties have been linked with nationalistic, anti-Turkish (Muslim), anti-communist, and anti-British feelings. ${ }^{37}$

ELAM declares that immigrants and asylum-seekers caused the deprivation of Greek Cypriots of scarce resources and jobs while weakening the island's Greek Orthodox demographic, religious, and cultural identity. Furthermore, ELAM also argues that demographic changes might happen because the majority of immigrants coming to the country are from Muslim countries. ${ }^{38}$ The discourses of anti-Muslim, anti-immigration, and rejection of multiculturalism often constitute common points of reference among those farright parties. One example is a decision to block the allowances provided for asylum-seekers by the majority of political parties in 2011.

\section{Inequivalent access to employment}

In employment sectors, however, reports still indicate that asylum seekers, migrant workers, non-white and Muslim Cypriots continue to face widespread discrimination in employment. An Iraqi man who has been in the RoC for seven years was terminated because he was determined to seek compensation for the damage he suffered after an accident at work. He also had

${ }^{36}$ Enes Bayrakli and Farid Hafez, European Islamophobia Report 2017, Istanbul: SETA I Foundation for Political, Economic and Social Research (2017), p. 15

37 Yiannos Katsourides, "Determinants of Extreme Right Reappearance in Cyprus: The National Popular Front (ELAM), Golden Dawn's Sister Party," South European Society and Politics, Volume 18, Number 4 (June 2013), p. 570-576

38 Yiannos Katsourides, "Determinants of Extreme Right Reappearance in Cyprus..., p. 576 
no chance to get any assistance from the welfare office. ${ }^{39}$ The only way to secure his right is by obtaining citizenship, which is almost impossible to achieve.

Besides, Article 28 (1) of the constitution of the RoC provides everyone's equality before the law, both in administration and justice. Furthermore, everyone is also entitled to equal protection and treatment. Furthermore, Article 28 (2) emphasizes that every person shall enjoy the rights provided in the constitution without any form of discrimination based on their community, race, religion, language, sex, social class, or any ground whatsoever.

Unfortunately, the law is not applied in everyday life in the RoC. Trimikliniotis's qualitative research (2003) found that discriminatory, xenophobic, and racist behaviors and attitudes are widespread at the grassroots level discourse of everyday life in the RoC, particularly in the workplace. Furthermore, discrimination continued to the top level to the state authorities, including immigration authorities, local state bureaucracies, and civil servants, as has also been discussed above. ${ }^{40}$ Therefore, not only face pressure from the bottom level of the social community but also migrants have difficulty when dealing with authorities at the top level. This situation has made migrants' life on the island more difficult.

\section{Conclusion}

This research found that migrants' issue has actively contributed to the discrimination and Islamophobic behaviors and attitudes toward Muslims. Even though the phenomenon of discrimination against migration, particularly Muslims, has its root in the history of the RoC, the discourse of demographic changes caused by migration influx would be the primary concern of the entity in the country. Immigrants, particularly Muslims, are always portrayed as a threat to the value of nationalism, culture, and identity of the country. Especially when it comes to religious discourse. The existence of Muslims on the island perceived as the cause of the decline of the Greek Cypriot population. The issue of the mass migration to the island affected the emergence of concern, which manifested into the appearance of far-right political parties. The ideology of

39 David Officer and Yiouli Taki, The Needs of Refugees and the Integration Process in Cyprus, The Refugee and Subsidiary Protection Community in Cyprus (2013), p. 69

40 Nicos Trimikliniotis and Mihaela Souroulla, "New Female Migration and Integration Related Policies in Cyprus," in Kontos, Maria, and Krystyna Slany (ed) The New Female Migrants in European Societies - a State of the Art, Krakow: Jagiellonian Univesity Press (2010), p. 179 
these parties has linkages to the idea of nationalistic, anti-immigrant, particularly Muslims.

Nevertheless, this social issue might be tackled on the multicultural policy and integration into society into systems and institutions. The government had passed several laws providing the equality of rights and liberties of every people. Unfortunately, the provisions of the constitution were not applied in the reality of the country's everyday life. Furthermore, not only on the bottom level of society, but also discrimination toward migrants happens at the top level of state authorities. Thus, such a phenomenon of discrimination would never disappear from life, unless the government of the RoC and every entity of the people of Cyprus have a sincere will and intention to live in peace and accept multiculturalism

\section{References}

Agency, A. (2016, February 22). Arson Attack Stagesd on Mosque in Greek Cyprus, Leaders Condemn Assault. Retrieved from Hurriyet Daily News: https://www.hurriyetdailynews.com/arson-attack-staged-on-mosquein-greek-cyprus-leaders-condemn-assault-95551

Amilianides, A., Adamides, C., \& Eftychiou, E. (2011). Allocation of Religious Space in Cyprus. The Cyprus Review, 97-121.

Antonopoulos, P. (2019, June 2). Mosque in Limassol Attacked. Retrieved from Greek City Times: https://greekcitytimes.com/2020/06/04/mosque-inlimassol-attacked/

Barkey, K., \& Gavrilis, G. (2015, December). The Ottoman Millet System: NonTerritorial Autonomy and Its Contemporary Legacy. Ethnopolitics, 15(1), 24-42.

Bayrakli, E., \& Hafez, F. (2017). European Islamophobia Report 2017. Istanbul: SETA.

Buzan, B. (1997). Security: A New Framework for Analysis. London: Lynne Publisher.

Constitute. (2020, June 12). Cyprus's Constitution of 1960 with Amendments through 2013. Retrieved from constituteproject: https://www.constituteproject.org/constitution/Cyprus_2013.pdf?lang $=$ en

Coufoudakis, V. (2004). Cyprus - The Referendum and Its Aftermath. The Cyprus Review, 6(2), 67-82. 
Cyprus, R. o. (2020, June 18). Statistical Service. Retrieved from www.mof.gov.cy: https://www.mof.gov.cy/mof/cystat/statistics.nsf/populationcondition _22main_en/populationcondition_22main_en?OpenForm\&sub=1\&sel=2

Dayioglu, A., \& Hatay, M. (2010). Cyprus. In J. S. Nielsen, Yearbook of Muslims in Europe. Leiden: Koninklijke Brill.

Dayioglu, A., \& Hatay, M. (2013). Cyprus. In J. S. Nielsen, Yearbook of Muslims in Europe. Leiden: Koninklijke Brill.

Dayioglu, A., \& Hatay, M. (2014). Cyprus. In J. S. Nielsen, Yearbook of Muslims in Europe. Leiden: Koninklijke Brill.

Demetriou, O. (2019). Migration into the Cyprus Conflict and the Cypriot Citizenship Regime. Oslo: Peace research Institute Oslo.

Demosthenous, A. (2018). Cyprus: National Identity and Images of Self and Others in History of Textbooks. In E. Podeh, \& S. Alayan, Multiple Alterities: Views pf Others in Textbooks of the Middle East. Jerusalem: Palgrave Macmillan.

ECRI. (2013). ECRI Report on Cyprus (Fourth Monitoring Cycle). Directorate General of Human Rights and Legal Affairs.

Holland, R. (1998). British and the Revolt in Cyprus 1954-1959. Oxford: carlendon Press.

Katsourides, Y. (2013, June). Determinant of Extreme Right Reappearance in Cyprus: The National Popular Front (ELAM), Golden Dawn's Sister Party. South European Society and Politics, 18(4), 567-589.

KISA. (2018, January 6). KISA condemns the latest bout of hate speech by the Archbishop of Cyprus. Retrieved from kisa.org.cy: https://kisa.org.cy/kisa-condemns-the-latest-bout-of-hate-speech-bythe-archbishop-of-cyprus/

Klein, G. B. (2018). Applied Linguistics to Identify and Contrast Racist 'Hate Speech': Cases from the English and Italian Language. Applied Linguistics Research Journal, 2(3), 1-16.

Muftuler-Bac, M., \& Guney, A. (2005). The European Union and the Cyprus Proble 1961-2003. Middle Eastern Studies, 41(2), 281-293.

Nevzat, A., \& Hatay, M. (2009, November). Politics, Society and the Decline of Islam in Cyprus: From the Ottoman Era to the Twenty-First Century. Middle Eastern Studies, 45(6), 37-41. 
Officer, D., \& Taki, Y. (2013). The Needs of Refugees and the Integration Process in Cyprus. Nicosia: The Refugee and Subsidiary Protection Community in Cyprus.

Panayi, P. (2009). Introduction: Ethnic Minority Creation in Modern Europe: Cyprus in Context. In A. Varvana, N. Coureas, \& M. Elia, The Minorities of Cyprus: Development Patterns and the Identity of the Internal-Exclusion. Newcastle: Cambridge Scholars Publising.

Philippou, S. (2009, March). What Makes Cyprus European? Curricular Responses of Greek-Cypriot Civic Education to 'Europe'. Journal of Curriculum Studies, 41(2), 37-41.

Ramadhan, R. (2020). The Roots of Secularism in Northern Cyprus and Turkey's Ambition of Islamization. Ijtima'iyya: Journal of Muslim Society Research, 5(2), 119-132

Reporter, S. (2020, June 10). Religious Freedom Report Refers to Headscarf Incident in High School. Retrieved from Cyprus Mail: https://cyprusmail.com/2020/06/10/religious-freedom-report-refers-to-headscarfincident-in-high-school/

Trimikliniotis, N., \& Souroulla, M. (2010). New Female Migration and Integration Related Policies in Cyprus. In Kontos, Maria, \& K. Slany, The New Female Migrants in European Societies - a State of the Art (pp. 166-185). Krakow: Jagielonian University.

Trimiklinotis, N. (2019). Nationality and Citizenship in Cyprus since 1945: Communal Citizenship, Gendered nationality, and the Adventures of Post-Colonial Subject in a Devided Country. In R. Baubock, B. Perching, \& W. Sievers, Citizenship Policies in the New Europe: Expanded and Updated Edition. Amsterdam: Amsterdam University Press.

Tsatsou, M. (2012, April 17). Fire in Cypriot Mosque Fuels Political Issue. Retrieved from Greek Reporter: https://eu.greekreporter.com/2012/04/17/fire-in-cypriot-mosquefuels-political-issue/

UNSCR. (1983, November 18). Resolution 541. Retrieved from unscr.com: http://unscr.com/en/resolutions/541

UNSCR. (1984, May 11). Resolution 550. Retrieved from unscr.com: http://unscr.com/en/resolutions/550

Webster, C. (2005, Augustus). Division or Unification in Cyprus? The Role of 
Demographics, Attitudes and Party Inclination on Greek Cypriot Preferences for a Solution to the Cyprus Problem. Ethnopolitics: Formerly Global Review of Ethnopolitics, 4(3), 299-309.

Worldometers. (2020, June 18). Cyprus Population. Retrieved from Worldometers: https://www.worldometers.info/worldpopulation/cyprus-population/

Yesilada, B. (2009). Islam and the Turkish Cypriot. Social Compass, 56(1), 49-59.

Yildiz, N. (2009). The Vakf Institution in Ottoman Cyprus. In M. N. Michael, M. Kappler, \& E. Gavrie, Ottoman Cyprus: A Collective of Studies on History and Culture. Wiesbaden: Otto Harrassowitz GmbH \& Co. KG. 